\title{
Improving DNA isolation from honey for the botanical origin identification
}

\author{
Sónia Soares ${ }^{a}$, Joana S. Amaral ${ }^{a, b, *}$, Maria Beatriz P.P. Oliveira ${ }^{a}$, Isabel Mafra ${ }^{a, *}$ \\ ${ }^{a}$ REQUIMTE, Departamento de Ciências Químicas, Faculdade de Farmácia, Universidade do Porto, Rua de Jorge Viterbo Ferreira, 228, 4050-313 Porto, \\ Portugal \\ ${ }^{\mathrm{b}}$ Instituto Politécnico de Bragança, Campus de Sta. Apolónia, 5301-857 Bragança, Portugal
}

\section{A R T I C L E I N F O}

\section{Article history:}

Received 7 December 2013

Received in revised form

14 February 2014

Accepted 19 February 2014

Available online 28 February 2014

\section{Keywords:}

Honey

DNA extraction

PCR amplification

Authenticity

Botanical identification

\begin{abstract}
A B S T R A C T
Honey is a natural product highly consumed due its known association with health benefits. Monofloral honeys are perceived as better quality products, being the most appreciated by consumers, thus attaining higher market values. Therefore efficient tools are needed as alternatives to the classical microscopic analysis presently used for the botanical origin identification of honey. In the present work, the use of DNA-based methods for the botanical species identification of honey is proposed. For this purpose, five DNA extraction methods (the kits NucleoSpin Plant (methods A and B) and DNeasy Plant Mini Kit, and the in-house CTAB-based and Wizard methods) combined with three different sample pre-treatments were applied to four honey samples ( 3 monofloral honeys of Calluna vulgaris, Lavandula spp. and Eucalyptus spp. and one multifloral honey). The 15 DNA extraction protocols were compared in terms of DNA integrity, yield and purity, as well as capacity of amplification targeting universal and adh1 specific genes of $C$. vulgaris. The results demonstrated the superior efficacy of the Wizard method in terms of DNA quality and amplification capacity, when combined with the sample preparation treatment with a mechanical disruption step of pollen to improve DNA yield. Although with considerable lower DNA yields, the CTAB and DNeasy methods were also successful because both were able to clearly amplify heather DNA from the monofloral heather honey.
\end{abstract}

(c) 2014 Elsevier Ltd. All rights reserved.

\section{Introduction}

In the last years, the increase of population concern with health and well-being has led to a growing demand for natural food products. In particular, the rising interest towards foods associated with therapeutic and healing properties has increased their value, making them vulnerable targets to economic frauds. Honey, a natural food produced by Apis mellifera bees, is among those products since it is highly consumed for its appreciated taste and also for its potential health benefits and biological properties (AlWaili \& Boni, 2003; Viuda-Martos, Ruiz-Navajas, FernándezLópez, \& Pérez-Álvarez, 2008; Wang, Andrae, \& Engeseth, 2002). Honey can be classified as monofloral, when arising predominantly from a single botanical origin (generally one plant species

\footnotetext{
* Corresponding authors. REQUIMTE, Departamento de Ciências Químicas, Faculdade de Farmácia, Universidade do Porto, Rua de Jorge Viterbo Ferreira, 228, 4050-313 Porto, Portugal. Tel.: +351 220428640; fax: +351 226093390.

E-mail addresses: jamaral@ipb.pt (J.S. Amaral), isabel.mafra@ff.up.pt (I. Mafra).
}

represents more than $45 \%$ of the total pollen content), or multifloral. Because of its refined flavour and taste, monofloral honeys are perceived as better quality products, being the most appreciated by consumers, thus attaining higher market values. Owing to its higher economic value together with the increasing world global trade, monofloral honeys are particularly prone to adulteration through incorrect labelling and fraudulent admixing with cheaper and lower quality honey. In order to protect consumers and promote fair competition among producers, there is a growing need to assess honey's authenticity, in particular to develop methodologies that allow establishing the botanical origin of honey.

Currently, the traditional method used for ascertaining the origin of honey is melissopalynology, which relies on pollen identification by microscopic analysis to determinate the plants visited by the bees during honey's production. However, this method is time consuming, requires the availability of a comprehensive collection of pollen grains and must be performed by experts with adequate skills and experience to identify pollen grains based on its different morphologies. Consequently, in the last years, several other methodologies have been proposed for the determination of 
the botanical origin of honey samples, including the assessment of different chemical parameters such as free amino acids (Hermosi; n, Chicón, \& Dolores Cabezudo, 2003), phenolic compounds (Escriche, Kadar, Juan-Borrás, \& Domenech, 2014), organic acids (Suárez-Luque, Mato, Huidobro, Simal-Lozano, \& Sancho, 2002) and volatile compounds (Cuevas-Glory, Pino, Santiago, \& Sauri-Duch, 2007), by means of different analytical instrumentation, including spectroscopic techniques (Arvanitoyannis, Chalhoub, Gotsiou, Lydakis-Simantiris, \& Kefalas, 2005; Ruoff et al., 2006). Nevertheless, the chemical composition of honeys with the same botanical origin may be quite different since plant phytochemicals can vary widely (due to edaphoclimatic factors, soil, flower maturity, etc.), making this an unreliable approach for the unequivocal botanical classification of honey (Arvanitoyannis et al., 2005; Kaškonienè \& Venskutonis, 2010). Moreover, the need for chemometrics to analyse chemical data often makes it rather difficult to draw reliable conclusions regarding unknown samples. To overcome these drawbacks, the use of DNA markers present in pollen to specifically identify the botanical species of honey is a novel and promising approach. The use of DNA-based methods offer advantages in terms of rapidity, sensitivity and specificity, being suitable for standardisation and thus an alternative to the traditional melissopalynological analysis (Laube et al., 2010). However, to successfully achieve DNA amplification by polymerase chain reaction (PCR), the use of efficient DNA extraction protocols is critical. Ideally, the method of choice should be able to provide high quantity and quality DNA extracts, without potential interfering PCR inhibitors. When dealing with complex matrices having low amounts of target DNA, such as honey, the selection of an adequate DNA extraction method is even more important. Honey is mainly composed of different sugars, but also contains other substances such as organic acids, polyphenols, pigments, enzymes and solid particles as waxes (Codex alimentarius, 2001), which are considered as being PCR inhibitors. Pollen is also present as a characteristic constituent, but at very low levels. For these reasons, sample preparation to isolate pollen particles and eliminate undesirable compounds, such as sugars and flavonoids, are required prior to DNA extraction (Cheng et al., 2007; Laube et al., 2010).

In previous studies, DNA extraction of pollen from honey samples has been reported both by using in-house extraction methods or commercial DNA extraction kits. Cheng et al. (2007) and Waiblinger et al. (2012) both used CTAB-based extraction methods in order to isolate DNA from honey and evaluate the presence of genetically modified organisms. The use of DNeasy Blood and Tissue Kit (Qiagen $\mathrm{GmbH}$ ) was reported in other works aiming at detecting DNA from different plant species in honey samples (Laube et al., 2010; Valentini, Miquel, \& Taberlet, 2010). Recently, Guertler, Eicheldinger, Muschler, Goerlich, and Busch (2014) reported the development of an automated DNA extraction method from pollen in honey and compared its performance with a manual CTAB buffer-based DNA isolation method. Although the automated method proved to be faster than the manual and resulted in higher DNA yield, it requires the use of high-cost instrumentation. However, there is still a scarcity of data concerning comparative analysis of the performance of different DNA extraction methods applied to honey samples.

In the present study, three different sample preparation treatments combined with five different DNA extraction methods were evaluated for the extraction of honey samples of four different botanical origins. The methods were selected taking into consideration previously reported results for DNA extraction from other complex food matrices and included both in-house and commercial kits. The performance of the methods was assessed and compared concerning both the extraction efficiency (DNA quantity and purity) and DNA suitability for amplification.

\section{Materials and methods}

\subsection{Sample preparation}

Three different monofloral honeys and one multifloral were used in this work. The monofloral honey samples of heather (Calluna vulgaris), lavender (Lavandula spp.) and the multifloral honey were acquired from local producers in the northeast region of Portugal (Trás-os-Montes), while the eucalyptus (Eucalyptus spp.) honey was obtained from the northwest region of Portugal (Passos de Ferreira). Prior to DNA extraction, each honey was submitted to three different sample preparations, named $a, b$ and $c$ :

- Pre-treatment $a$ was performed as described by Cheng et al. (2007) with minor modifications. A sample of $50 \mathrm{~g}$ $(4 \times 12.5 \mathrm{~g})$ of honey was weighted into four $50 \mathrm{~mL}$ Falcon tubes, $2 \mathrm{~mL}$ of ultrapure water were added to each tube and the mixtures were stirred. Then, $12 \mathrm{~mL}$ of phosphate buffered saline solution (PBS) $\left(136 \mathrm{mM} \mathrm{NaCl}, 1.4 \mathrm{mM} \mathrm{KH}_{2} \mathrm{PO}_{4}, 2.6 \mathrm{mM} \mathrm{KCl}\right.$, $8.09 \mathrm{mM} \mathrm{Na}_{2} \mathrm{HPO}_{4} \cdot 12 \mathrm{H}_{2} \mathrm{O}, \mathrm{pH} 7.2$ ) were added to each tube and the mixtures was homogenised for $3 \mathrm{~min}$. After centrifuging at $12,000 \mathrm{~g}$ for $20 \mathrm{~min}$, the supernatants were discarded. The pellets were re-suspended and combined in $1 \mathrm{~mL}$ of ultrapure water and $1 \mathrm{~mL}$ of PBS, transferred to a $2 \mathrm{~mL}$ tube and centrifuged at 12,000 $\mathrm{g}$ for $20 \mathrm{~min}$. The supernatant was discarded and the pellet was stored at $-20^{\circ} \mathrm{C}$ until subsequent DNA extraction.

- Pre-treatment $b$ was performed by homogenising $50 \mathrm{~g}$ of honey sample in $180 \mathrm{~mL}$ of ultrapure water and subsequent distribution of the mixture into four sterile $50 \mathrm{~mL}$ centrifugation tubes, which were incubated at $65{ }^{\circ} \mathrm{C}$ for $30 \mathrm{~min}$ with stirring. The mixture was centrifuged for $30 \mathrm{~min}$ at $12,000 \mathrm{~g}$, the supernatant was discarded, and each pellet was re-suspended in $400 \mu \mathrm{L}$ of distilled water, which were further combined into one $2 \mathrm{~mL}$ tube. The suspension was placed in an ultrasonic bath (FungiLab SA, Barcelona, Spain) during $2 \mathrm{~min}$. The mixture was stored at $-20^{\circ} \mathrm{C}$ until subsequent DNA extraction.

- Pre-treatment $c$ was performed based on a protocol proposed by Waiblinger et al. (2012) with some modifications. Fifty grams of honey sample were distributed into four sterile $50 \mathrm{~mL}$ centrifugation tubes ( $12.5 \mathrm{~g}$ honey per tube), followed by the addition of $40 \mathrm{~mL}$ of ultrapure water to each tube, stirring and incubation at $40{ }^{\circ} \mathrm{C}$ for $10 \mathrm{~min}$. After centrifugation for $10 \mathrm{~min}$ at $11,000 \mathrm{~g}$, the supernatants were discarded, each pellet re-suspended in $5 \mathrm{~mL}$ of ultrapure water and combined in one $50 \mathrm{~mL}$ tube. The suspension was diluted with ultrapure water until a volume of approximately $45 \mathrm{~mL}$ and centrifuged for $10 \mathrm{~min}$ at $11,000 \mathrm{~g}$. The supernatant was discarded, the pellet was re-suspended in approximately $0.5 \mathrm{~mL}$ of ultrapure water and transferred to a $2 \mathrm{~mL}$ reaction tube containing 7 glass beads (particle size approximately $500 \mu \mathrm{m}$ ). After vortex stirring the suspension for $2 \mathrm{~min}$, the glass beads were removed. The mixture was stored at $-20^{\circ} \mathrm{C}$ until subsequent DNA extraction.

\subsection{DNA extraction}

The pre-treated samples with the above mentioned 3 procedures were extracted using five different methods: Nucleospin A, Nucleospin B, DNeasy, Wizard and CTAB.

\subsubsection{Nucleospin A and Nucleospin B}

The NucleoSpin methods were based on the use of the commercial kit NucleoSpin ${ }^{\circledR}$ Plant II (Macherey-Nagel, Düren, Germany) and performed according to the manufacture instructions with some minor modifications. This kit included two methods of 
Table 1

Oligonucleotide primers used in qualitative PCR.

\begin{tabular}{|c|c|c|c|c|}
\hline Gene & Name & Sequence $5^{\prime}-3^{\prime}$ & Amplicon length (bp) & References \\
\hline \multirow[t]{2}{*}{ Nuclear 18S rRNA } & 18SRG-F & CT GCC CTA TCA ACT TTC GAT GG TA & 113 & (Costa, Oliveira, \& Mafra, 2013) \\
\hline & 18SRG-R & TTG GAT GTG GTA GCC GTT TCT CA & & \\
\hline \multirow[t]{2}{*}{ Alcohol dehydrogenase 1 (adh1) } & Eri_adh1-f & GGA TAG GGG AGT GAT GAT CCA T & 81 & (Laube et al., 2010) \\
\hline & Eri_adh1-r & GAT GTT CCG ACG AAA TGG TAT ATG & & \\
\hline
\end{tabular}

extraction, namely Nucleospin Plant II A and Nucleospin Plant II B owing to some minor differences during the cell lysis step. To each pre-treated sample in $2 \mathrm{~mL}$ tubes, $400 \mu \mathrm{L}$ of Buffer PL1 and $300 \mu \mathrm{L}$ of Buffer PL2 were added in methods A and B, respectively, and the mixtures were incubated at $65{ }^{\circ} \mathrm{C}$ for $1 \mathrm{~h}$ with gentle stirring. Ten minutes before the end of incubation, $4 \mu \mathrm{L}$ of RNase $\mathrm{A}\left(10 \mathrm{mg} \mathrm{mL}^{-1}\right)$ were added to both methods. Afterwards, $75 \mu \mathrm{L}$ of PL3 solution were added to the mixture of method $B$ that was incubated at $4{ }^{\circ} \mathrm{C}$ for $5 \mathrm{~min}$. The mixtures of methods $\mathrm{A}$ and $\mathrm{B}$ were centrifuged for $10 \min \left(17,000 \mathrm{~g}, 4^{\circ} \mathrm{C}\right)$. The supernatants were passed through the kit filters by centrifugation for $2 \min \left(11,000 \mathrm{~g}, 4^{\circ} \mathrm{C}\right)$ and the filtered solutions were collected in new sterile reaction tubes and. The filters were rejected and $450 \mu \mathrm{L}$ of Buffer PC were added to the filtrates and mixed by inversion in both methods. The mixtures were passed through new columns by centrifugation during $1 \mathrm{~min}$ $\left(11,000 \mathrm{~g}, 4^{\circ} \mathrm{C}\right)$, discarding the eluted liquid. The columns were washed three times: the first wash with $400 \mu \mathrm{L}$ of Buffer PW1, the second and third washes with 700 and $200 \mu \mathrm{L}$ of Buffer PW2, respectively, followed by 1 min centrifugation $\left(11,000 \mathrm{~g} ; 4^{\circ} \mathrm{C}\right)$ after the first and second washings and a centrifugation for $2 \mathrm{~min}$ $\left(11,000 \mathrm{~g} ; 4^{\circ} \mathrm{C}\right)$ after the final one. The DNA was eluted from the column by adding $100 \mu \mathrm{L}$ of Buffer PE pre-heated at $65^{\circ} \mathrm{C}$, followed by $5 \mathrm{~min}$ incubation period at $65{ }^{\circ} \mathrm{C}$ and centrifugation for $1 \mathrm{~min}$ $\left(11,000 \mathrm{~g}, 4^{\circ} \mathrm{C}\right)$.

\subsubsection{DNeasy}

The DNeasy extraction method consisted on the use of the commercial kit DNeasy ${ }^{\circledR}$ Plant Mini Kit (Qiagen, Mississauga, Canada), according to the manufacturer's instructions.

\subsection{3. $C T A B$}

The CTAB-based method was performed as described by Mafra, Silva, Moreira, da Silva, and Oliveira (2008) with some modifications. To each pre-treated sample, $1 \mathrm{~mL}$ of CTAB-PVP extraction buffer (1\% polyvinylpyrrolidone (PVP-40); $20 \mathrm{mM}$ EDTA; 100 mM Tris-HCl; pH 7.5; $1.4 \mathrm{M} \mathrm{NaCl} ; 2 \% \mathrm{w} / \mathrm{v}$ CTAB (cetyltrimethylammonium bromide)) and $20 \mu \mathrm{L}$ of $\beta$-mercaptoethanol were added. The mixture was vortex stirred and incubated for $1 \mathrm{~h}$ at $65{ }^{\circ} \mathrm{C}$ in a Thermomixer Comfort (Eppendorf AG, Hamburg, Germany) with stirring. The suspension was centrifuged for $15 \mathrm{~min}$ $\left(17,000 \mathrm{~g}, 4^{\circ} \mathrm{C}\right)$, the supernatant were passed to a new tube and centrifuged again for $5 \mathrm{~min}\left(17,000 \mathrm{~g}, 4^{\circ} \mathrm{C}\right)$. The supernatant was transferred into new tube with $500 \mu \mathrm{L}$ of chloroform, vortex stirred and centrifuged for $10 \mathrm{~min}\left(12,000 \mathrm{~g}, 4^{\circ} \mathrm{C}\right)$. The upper phase was transferred to a new tube, mixed with a double volume of CTAB precipitation solution $\left(5 \mathrm{~g} \mathrm{~L}^{-1}, 0.04 \mathrm{M} \mathrm{NaCl}\right)$ and incubated for $1 \mathrm{~h}$ at room temperature. After centrifugation for $10 \mathrm{~min}\left(12,000 \mathrm{~g}, 4^{\circ} \mathrm{C}\right)$, the supernatant was discarded and the precipitate was dissolved in $350 \mu \mathrm{L}$ of $1.2 \mathrm{M} \mathrm{NaCl}$ solution and extracted with $350 \mu \mathrm{L}$ chloroform. The mixture was centrifuged for $10 \mathrm{~min}\left(12,000 \mathrm{~g} ; 4^{\circ} \mathrm{C}\right)$ and the upper phase was mixed by inversion with 0.6 volume parts of isopropanol at $-20^{\circ} \mathrm{C}$. The mixture was centrifuged for $10 \mathrm{~min}$ $\left(12,000 \mathrm{~g}, 4^{\circ} \mathrm{C}\right)$, the supernatant was discarded and the pellet was washed with $500 \mu \mathrm{L}$ of ethanol solution $(70 \%, \mathrm{v} / \mathrm{v})$ at $-20^{\circ} \mathrm{C}$. After centrifugation, the supernatant was carefully discarded by
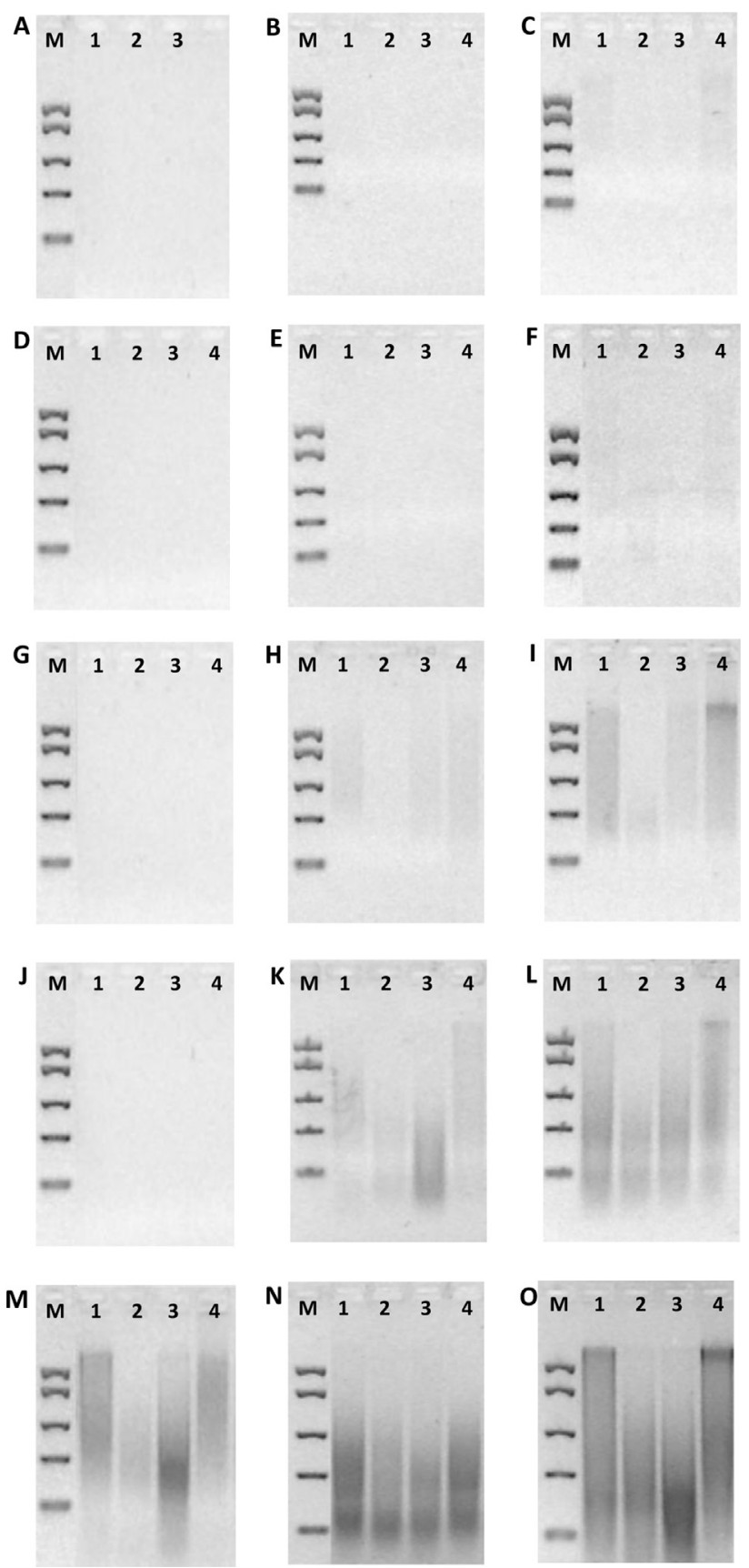

Fig. 1. Agarose gel electrophoresis of DNA extracted from honey samples using three different pre-treatments (Pre-treatment $a-\mathrm{A}, \mathrm{D}, \mathrm{G}$, J and M, Pre-treatment $b-\mathrm{B}, \mathrm{E}, \mathrm{H}$, $\mathrm{K}$ and $\mathrm{N}$, Pre-treatment $c-\mathrm{C}, \mathrm{F}, \mathrm{I}, \mathrm{L}$ and $\mathrm{O})$ combined with five different extraction methods: Nucleospin A (A, B and C); Nucleospin B (D, E and F); Dneasy (G, H and I); CTAB (J, K and L); Wizard (M, N and O). Legend: M, DNA ladder (Thermo Scientific, Carlsbad, CA, USA); lane 1-3, monofloral honey samples of heather, lavender and eucalyptus respectively; lane 4 , multifloral honey sample. 
pipetting, the pellet was dried and the DNA was dissolved in $100 \mu \mathrm{L}$ of Tris-EDTA buffer (10 mM Tris, 1 mM EDTA).

\subsubsection{Wizard}

The Wizard method was performed as described by Mafra et al. (2008) with minor modifications. Briefly, to each pre-treated sample, $860 \mu \mathrm{L}$ of pre-heated at $60{ }^{\circ} \mathrm{C}$ TNE extraction buffer (10 mM Tris, $150 \mathrm{mM} \mathrm{NaCl}, 2 \mathrm{mM}$ EDTA, 1\% SDS), $100 \mu \mathrm{L}$ of $5 \mathrm{M}$ guanidine hydrochloride solution and $40 \mu \mathrm{L}$ proteinase $\mathrm{K}$ solution (20 $\mathrm{mg} \mathrm{mL}^{-1}$ ) were added and the mixture was vortex stirred. After incubation at $60{ }^{\circ} \mathrm{C}$ for $3 \mathrm{~h}$ in a Thermomixer Comfort (Eppendorf AG, Hamburg, Germany) with stirring, the suspension was centrifuged for $15 \mathrm{~min}\left(17,000 \mathrm{~g}, 4^{\circ} \mathrm{C}\right)$ and the supernatant were mixed with $1 \mathrm{~mL}$ of Wizard ${ }^{\circledR}$ DNA purification resin (Promega, Madison, WI, USA). The mixture was eluted through a Wizard ${ }^{\circledR}$ column and the retained resin was washed with $2 \mathrm{~mL}$ of isopropanol solution $(80 \%, v / v)$. After drying the column, the DNA was eluted with $100 \mu \mathrm{L}$ of Tris-EDTA buffer ( $10 \mathrm{mM}$ Tris, $1 \mathrm{mM}$ EDTA) at $70{ }^{\circ} \mathrm{C}$, by centrifugation for $1 \mathrm{~min}(10,000 \mathrm{~g})$, to a new reaction tube.

All the extracts were kept at $-20{ }^{\circ} \mathrm{C}$ until further analysis. All extractions included a blank for the control of reagents and contaminations during the extraction procedure. Each extraction method was performed in triplicate.

\subsection{DNA quality and purity}

The yield and purity of the extracts were assessed by UV spectrophotometry using a SynergyHT multi-mode microplate reader (BioTek Instruments, Inc., Vermont, USA) with a Take 3 microvolume plate accessory. The absorbance was read at 260 and $280 \mathrm{~nm}$ in order to estimate DNA content and purity using the nucleic acid quantification protocol with sample type defined for double-strand DNA in the Gen5 data analysis software version 2.01 (BioTek Instruments, Inc., Vermont, USA). The quality of extracted DNA was further analysed by electrophoresis in a 1.0\% agarose gel containing Gel Red $1 \times$ (Biotium, Hayward, CA, USA) for staining and carried out in SGTB $1 \times$ (GRiSP, Research Solutions, Porto, Portugal) for $20 \mathrm{~min}$ at $200 \mathrm{~V}$. The agarose gel was visualised under UV light and a digital image was obtained using a Kodak Digital Science ${ }^{\mathrm{TM}}$ DC120 (Rochester, NY, USA).

\subsection{PCR conditions}

The polymerase chain reaction (PCR) amplifications were carried out in a total reaction volume of $25 \mu \mathrm{L}$, containing $2 \mu \mathrm{L}$ of DNA (maximum of $50 \mathrm{ng}$ ) extract, $15 \mathrm{mM}$ Tris- $\mathrm{HCl}$ (pH 8.3), $50 \mathrm{mM} \mathrm{KCl}$, $0.25 \mu \mathrm{M}$ or $0.6 \mu \mathrm{M}$ of each primer Eri_adh1-f/Eri_adh1-r or 18SRGF/18SRG-R, respectively (Table 1), $0.2 \mathrm{mM}$ of each dNTP (Invitrogene, Carlsbad, CA, USA), $3.0 \mathrm{mM}$ or $1.5 \mathrm{mM}$ of $\mathrm{MgCl}_{2}$ for primers Eri_adh1-f/Eri_adh1-r or 18SRG-F/18SRG-R, respectively, and $1 \mathrm{U}$ of SuperHot Taq DNA polymerase (Genaxxon Bioscience GmbH, Ulm, Germany). The primers presented on Table 1 were synthesised by Eurofins MWG Operon (Ebersberg, Germany).

The reactions were performed in a thermal cycler MJ Mini (BioRad Laboratories, Hercules, CA, USA) using the following programs: (i) initial denaturation at $95{ }^{\circ} \mathrm{C}$ for $5 \mathrm{~min}$; (ii) 40 cycles (primers Eri_adh1-f/Eri_adh1-r) or 33 cycles (primers 18SRG-F/18SRG-R) at $95^{\circ} \mathrm{C}$ for $30 \mathrm{~s}, 58{ }^{\circ} \mathrm{C}$ (for Eri_adh1-f/Eri_adh1-r) or $65^{\circ} \mathrm{C}$ (for $18 S R G-$ $\mathrm{F} / 18 \mathrm{SRG}-\mathrm{R}$ ) for $30 \mathrm{~s}$ and $72{ }^{\circ} \mathrm{C}$ for $30 \mathrm{~s}$; (iii) and a final extension at $72{ }^{\circ} \mathrm{C}$ for $5 \mathrm{~min}$.

The amplified fragments were analysed by electrophoresis in a 1.5\% agarose gel containing Gel Red $1 \times$ (Biotium, Hayward, CA, USA) for staining and carried out in SGTB $1 \times$ (GRiSP, Research Solutions, Porto, Portugal. The agarose gel was visualised under UV light and a digital image was obtained using a Kodak Digital Science $^{\mathrm{TM}}$ DC120 (Rochester, NY, USA). Each extract was amplified at least in duplicate assays.

\section{Results and discussion}

\subsection{Qualitative and quantitative analysis of the extracted DNA}

In this work, the combination of three pre-treatments ( $a, b$ and $c$ ) with five DNA extraction methods gave 15 different DNA extraction protocols that were applied to 4 selected honey samples, including both mono and multifloral honeys. The quality of all the obtained extracts was assessed by agarose gel electrophoresis and UV spectrophotometry. The results of agarose gel electrophoresis (Fig. 1) show that visible DNA was obtained with the Wizard (Fig. 1M-O) method and, to a lesser extent, with CTAB (Fig. 1J-L) and DNeasy methods (Fig. $1 G-I$ ), while Nucleospin A and B did not

Table 2

Results of DNA yields and purity of four different honey samples extracted with 5 methods combined with three pre-treatments.

\begin{tabular}{|c|c|c|c|c|c|c|c|c|}
\hline \multirow[t]{3}{*}{ Extraction method } & \multicolumn{2}{|c|}{ Honey 1 (heather) } & \multicolumn{2}{|c|}{ Honey 2 (lavender) } & \multicolumn{2}{|c|}{ Honey 3 (eucalyptus) } & \multicolumn{2}{|c|}{ Honey 4 (multifloral) } \\
\hline & \multicolumn{8}{|l|}{ Mean $\pm \mathrm{SD}^{\mathrm{a}}$} \\
\hline & $\begin{array}{l}\text { Concentration } \\
(\mathrm{ng} / \mu \mathrm{L})\end{array}$ & $\begin{array}{l}\text { Purity } \\
\left(A_{260} / A_{280}\right)\end{array}$ & $\begin{array}{l}\text { Concentration } \\
(\mathrm{ng} / \mu \mathrm{L})\end{array}$ & $\begin{array}{l}\text { Purity } \\
\left(A_{260} / A_{280}\right)\end{array}$ & $\begin{array}{l}\text { Concentration } \\
(\mathrm{ng} / \mu \mathrm{L})\end{array}$ & $\begin{array}{l}\text { Purity } \\
\left(A_{260} / A_{280}\right)\end{array}$ & $\begin{array}{l}\text { Concentration } \\
(\mathrm{ng} / \mu \mathrm{L})\end{array}$ & $\begin{array}{l}\text { Purity } \\
\left(A_{260} / A_{280}\right)\end{array}$ \\
\hline \multicolumn{9}{|l|}{ Pre-treatment $a$} \\
\hline Nucleospin A & nd & - & nd & - & nd & - & nd & - \\
\hline Nucleospin B & nd & - & nd & - & nd & - & nd & - \\
\hline DNeasy & nd & - & nd & - & nd & - & nd & - \\
\hline CTAB & nd & - & nd & - & nd & - & nd & - \\
\hline $\begin{array}{l}\text { Wizard } \\
\text { Pre-treatment } b\end{array}$ & $109.9 \pm 9.4$ & $2.0 \pm 0.0$ & $24.7 \pm 7.4$ & $1.8 \pm 0.1$ & $22.7 \pm 0.11$ & $1.9 \pm 0.1$ & $40.1 \pm 2.31$ & $1.8 \pm 0.2$ \\
\hline Nucleospin A & $2.86 \pm 0.92$ & $1.0 \pm 0.1$ & nd & - & $4.19 \pm 2.14$ & $1.1 \pm 0.3$ & $3.47 \pm 0.61$ & $1.1 \pm 0.3$ \\
\hline Nucleospin B & $4.50 \pm 2.69$ & $1.6 \pm 0.2$ & $1.72 \pm 0.55$ & $1.7 \pm 0.5$ & $0.84 \pm 0.36$ & $1.1 \pm 0.6$ & $4.90 \pm 1.57$ & $1.5 \pm 0.2$ \\
\hline DNeasy & $14.3 \pm 3.0$ & $1.3 \pm 0.1$ & $9.43 \pm 1.81$ & $1.3 \pm 0.0$ & $10.0 \pm 0.15$ & $1.4 \pm 0.2$ & $20.5 \pm 2.2$ & $1.3 \pm 0.1$ \\
\hline СТАВ & $83.8 \pm 9.9$ & $2.1 \pm 0.1$ & $22.5 \pm 8.8$ & $2.1 \pm 0.1$ & $26.7 \pm 11.8$ & $2.1 \pm 0.0$ & $24.8 \pm 1.4$ & $2.0 \pm 0.1$ \\
\hline Wizard & $382.7 \pm 3.4$ & $2.1 \pm 0.0$ & $193.2 \pm 3.5$ & $2.0 \pm 0.0$ & $244.6 \pm 57.4$ & $1.9 \pm 0.0$ & $275.4 \pm 30.1$ & $2.0 \pm 0.0$ \\
\hline \multicolumn{9}{|l|}{ Pre-treatment c } \\
\hline Nucleospin A & $8.19 \pm 2.42$ & $1.5 \pm 0.1$ & $3.20 \pm 1.03$ & $1.1 \pm 0.1$ & $4.89 \pm 2.52$ & $1.2 \pm 0.2$ & $8.06 \pm 1.31$ & $1.3 \pm 0.0$ \\
\hline Nucleospin B & $12.6 \pm 8.8$ & $2.0 \pm 0.1$ & $5.16 \pm 1.43$ & $1.5 \pm 0.1$ & $1.59 \pm 2.01$ & $1.4 \pm 0.2$ & $8.38 \pm 1.19$ & $2.0 \pm 0.1$ \\
\hline DNeasy & $24.5 \pm 0.6$ & $1.7 \pm 0.0$ & $9.59 \pm 0.39$ & $1.5 \pm 0.1$ & $8.35 \pm 1.01$ & $1.5 \pm 0.1$ & $29.1 \pm 3.6$ & $1.5 \pm 0.1$ \\
\hline CTAB & $10.7 \pm 2.3$ & $1.9 \pm 0.2$ & $117.2 \pm 11.9$ & $2.1 \pm 0.1$ & $134.0 \pm 5.6$ & $2.1 \pm 0.0$ & $152.4 \pm 26.6$ & $2.1 \pm 0.1$ \\
\hline Wizard & $331.2 \pm 18.5$ & $2.0 \pm 0.0$ & $312.5 \pm 8.9$ & $2.1 \pm 0.0$ & $592.6 \pm 24.5$ & $2.1 \pm 0.0$ & $377.8 \pm 12.5$ & $2.1 \pm 0.0$ \\
\hline
\end{tabular}

a The results are presented as mean \pm standard deviation calculated for each extraction protocol in triplicate assays. 
show any DNA, regardless the sample pre-treatment (Fig. 1A-F). With the DNeasy and CTAB methods, visible sheared DNA was obtained with sample pre-treatment $c$, mainly for samples 1 and 4 that show high molecular mass DNA (Fig. 1I, L), but only traces or no detectable DNA for pre-treatments $b$ (Fig. $1 \mathrm{H}, \mathrm{K}$ ) and $a$ (Fig. 1G, J), respectively. In general, irrespectively of the pre-treatment used, the Wizard method was the one who exhibited the highest DNA intensity. Generally, it also allowed obtaining higher molecular mass DNA, which was particularly evidenced in samples 1 and 4 with pre-treatment $c$ (Fig. 10).

The results of DNA yield and purity of the four honey samples extracted with the combination of 3 pre-treatments and 5 methods are presented in Table 2. Generally, data were in good agreement with electrophoretic analysis, confirming the highest DNA yields for all the samples extracted with the Wizard method, followed by CTAB and DNeasy methods with considerable lower values, which is emphasised in Fig. 2. The higher DNA yield of extracts obtained with Wizard method is also emphasised comparing with other reports, which produced much lower values from honey samples extracted with CTAB method (9.5-39 ng/ $\mu \mathrm{L}$ ) (Waiblinger et al., 2012). In what concerns the different applied pre-treatments, Fig. 2 also allows to highlight that the best yields were achieved with pre-treatment $c$, while pre-treatment $a$ exhibited the worst results. This finding can be attributed to the poor cell disruption of pre-treatment $a$ since it consisted mainly of a washing step to isolate pollen granules. On the other hand, the pre-treatments $b$ and $c$ succeeded in cell disruption, but ultrasound applied in pre-treatment $b$ affected more severely the DNA integrity (Fig. $1 \mathrm{~N}$ ) than the mechanical treatment with glass spheres of pre-treatment $c$ (Fig. 10), justifying the highest DNA recoveries and integrity of the latter.

The purities obtained with both Wizard and CTAB methods were generally high (1.8-2.1), regardless the pre-treatment, while DNeasy method revealed lower (1.6) and poor purities (1.3) with pre-treatments $c$ and $b$, respectively (Table 2 ).

The Nucleospin A and B methods did not show detectable DNA with pre-treatment $a$, attaining only negligible amounts with the other two pre-treatments (Table 2). Considering the poor results of all the extraction protocols with pre-treatment $a$, this prior sample preparation step was considered not adequate for DNA extraction of pollen and was excluded from further assessment.

\subsection{PCR amplification}

To further evaluate the combination of pre-treatments $b$ and $c$ with the five DNA extraction methods, all the extracts were amplified with primers targeting a universal nuclear 18S rRNA gene. The amplification results show strong PCR products with the

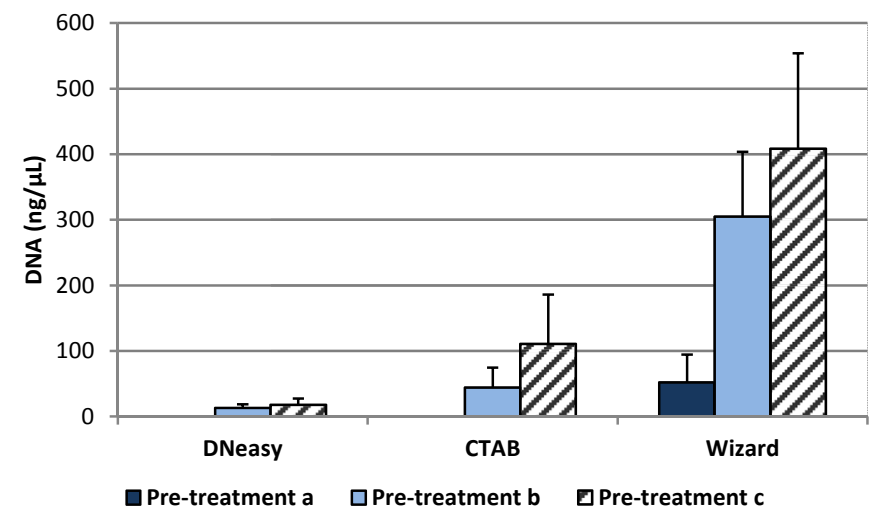

Fig. 2. Average DNA concentration of extracts from honey samples using different pretreatments and extraction methods. expected size of $113 \mathrm{bp}$ for the four honeys samples extracted with the 10 protocols (Fig. 3), suggesting the acceptability of all DNA extracts for PCR amplification.

To assess the suitability of extracted DNA as template for botanical origin identification, specific PCR primers were used to detect adh1 gene of heather (C. vulgaris), which is a plant species
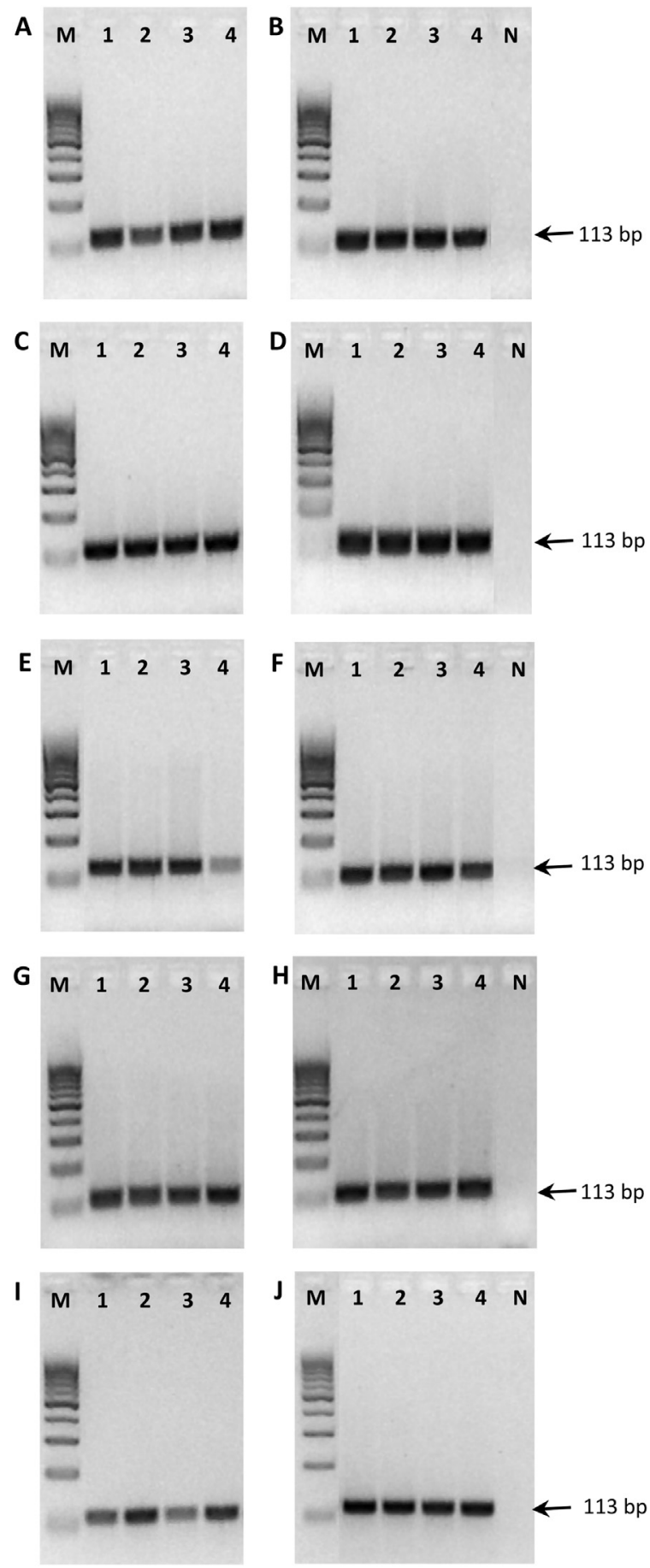

Fig. 3. Agarose gel electrophoresis of PCR products of eukaryotic gene amplified from honey samples prepared with two different pre-treatments (Pre-treatment $b-\mathrm{A}, \mathrm{C}, \mathrm{E}$, $\mathrm{G}$ and I, Pre-treatment $c-\mathrm{B}, \mathrm{D}, \mathrm{F}, \mathrm{H}$ and J) combined with five different DNA extraction methods: Nucleospin A (A); Nucleospin B (B); Dneasy (C); CTAB (D); Wizard (E). Legend: M, 100 bp DNA ladder (Bioron, Ludwigshafen, Germany); lane 1-3, monofloral honey samples of heather, lavender and eucalyptus, respectively; lane 4, multifloral honey sample; $\mathrm{N}$, negative control. 
commonly present in Portuguese flora. As expected, the fragment of 81 bp was obtained from almost all sample 1 extracts since it is a monofloral honey containing pollen predominantly from heather (Fig. 4). The samples 3 and 4 also amplified positively for the adh1
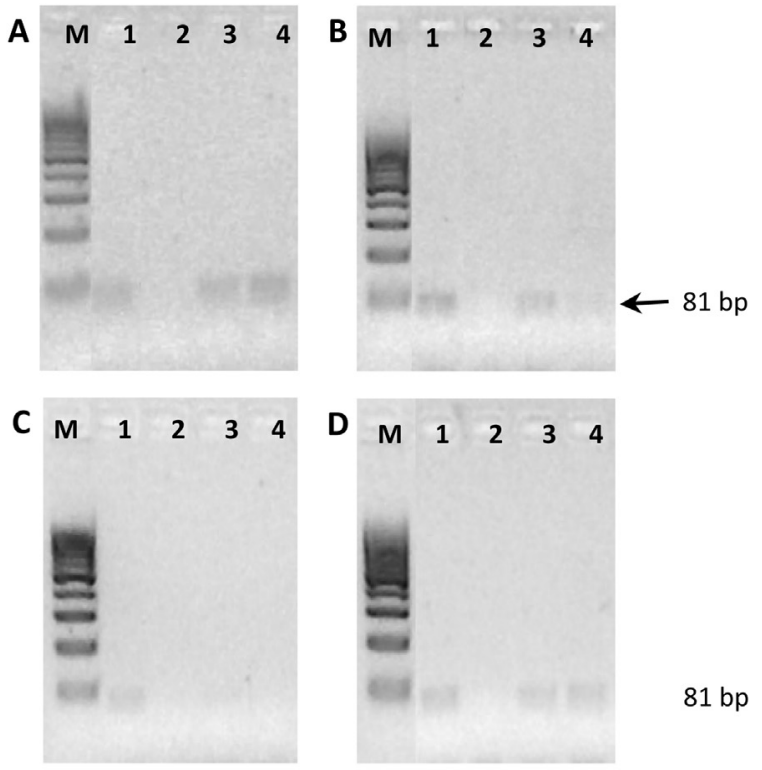

81 bp
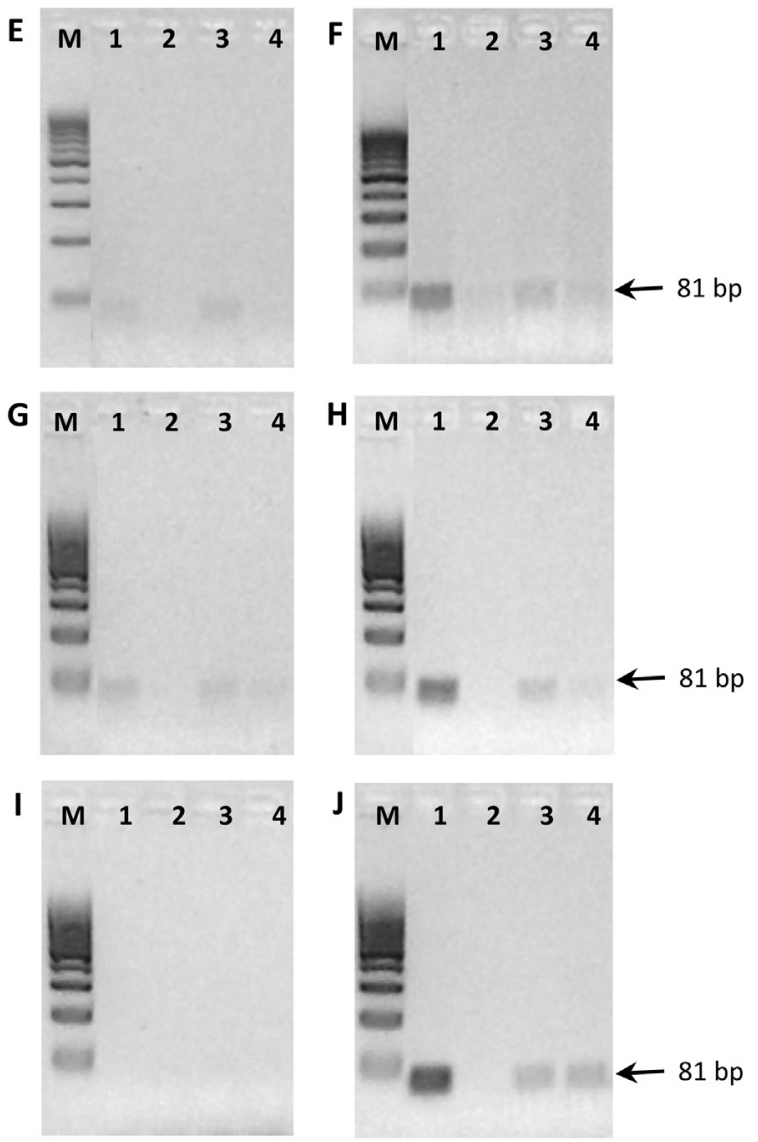

Fig. 4. Agarose gel electrophoresis of PCR products of adh1 gene of heather amplified from honey samples prepared with two different pre-treatments (Pre-treatment $b-\mathrm{A}$, $C, E, G$ and I, Pre-treatment $c-B, D, F, H$ and J) combined with five different DNA extraction methods: Nucleospin A (A); Nucleospin B (B); Dneasy (C); CTAB (D); Wizard (E). Legend: $M, 100$ bp DNA ladder (Bioron, Ludwigshafen, Germany); lane 1-3, monofloral honey samples of heather, lavender and eucalyptus, respectively; lane 4 , multifloral honey sample; $\mathrm{N}$, negative control. gene of heather in most extraction protocols, although with faint bands. These findings are in good agreement with the melissopalynological analysis that confirmed the presence of heather pollen in samples 3 and 4 . This was an expected result considering that monofloral honeys of other species such as eucalyptus (sample 3) might contain heather pollen, and even more, multifloral honeys such as sample 4 .

In what concerns the comparison of extraction protocols, the results confirm the superior efficacy of pre-treatment $c$ (Fig. 4), previously highlighted, especially when combined with Wizard method (Fig. 4J), followed by the DNeasy and CTAB methods (Fig. 4F, H). As referred, this is certainly related to the higher integrity of DNA extracted with pre-treatment $c$, in opposition to the sheared DNA obtained with pre-treatment $b$, which included a more aggressive step by the use of ultra-sounds.

\section{Conclusions}

In this work, different protocols were evaluated for its efficiency in extracting DNA from pollen present in honey samples. The results demonstrated the superior efficacy of Wizard method to extract DNA from honey pollen when combined with the pretreatment $c$ that included a mechanical pollen disruption step to improve yield. General parameters of quality evaluation of DNA extracts in terms of integrity, yield and purity, as well as universal and species-specific PCR amplification, all agreed with the best performance of Wizard method combined with pre-treatment $c$. Although with considerable lower DNA yields, the CTAB and DNeasy methods were also successful because in both cases the amplification of heather DNA from the monofloral heather honey was clearly achieved. Nucleospin A and Nucleospin B methods exhibited the worst performance since they produced the poorest or non-detectable DNA yields and the level of species-specific PCR amplification was low, in spite of the successful universal gene amplification. The obtained results indicate that molecular biology techniques, due to its fastness, sensitivity, specificity and lower margin for human subjectivity in the analysis of results, can be used as a suitable alternative to the traditional melissopalynology analysis.

\section{Acknowledgements}

This work has been supported by FCT through grants PEst-C/ EQB/LA0006/2013 and NORTE-07-0124-FEDER-000069-Food Science. S. Soares is grateful to FCT PhD grant (SFRH/BD/75091/2010) financed by POPH-QREN (subsidised by FSE and MCTES).

\section{References}

Al-Waili, N. S., \& Boni, N. S. (2003). Natural honey lowers plasma prostaglandin concentrations in normal individuals. Journal of Medicinal Food, 6, 129-133.

Arvanitoyannis, I. S., Chalhoub, C., Gotsiou, P., Lydakis-Simantiris, N., \& Kefalas, P. (2005). Novel quality control methods in conjunction with chemometrics (multivariate analysis) for detecting honey authenticity. Critical Reviews in Food Science and Nutrition, 45, 193-203.

Cheng, H., Jin, W., Wu, H., Wang, F., You, C., Peng, Y., et al. (2007). Isolation and PCR detection of foreign DNA sequences in bee honey raised on genetically modified Bt (Cry 1 Ac) cotton. Food and Bioproducts Processing, 85, 141-145.

Codex alimentarius. (2001). Revised codex standard for honey (No. CODEX STAN 12-1981), Rev. 1 (1987). 11 (Rev. 2), pp. 1-8.

Costa, J., Oliveira, M. B. P. P., \& Mafra, I. (2013). Effect of thermal processing on the performance of the novel single-tube nested real-time PCR for the detection of walnut allergens in sponge cakes. Food Research International, 54, 1722-1729.

Cuevas-Glory, L. F., Pino, J. A., Santiago, L. S., \& Sauri-Duch, E. (2007). A review of volatile analytical methods for determining the botanical origin of honey. Food Chemistry, 103, 1032-1043.

Escriche, I., Kadar, M., Juan-Borrás, M., \& Domenech, E. (2014). Suitability of antioxidant capacity, flavonoids and phenolic acids for floral authentication of honey. Impact of industrial thermal treatment. Food Chemistry, 142, 135-143. 
Guertler, P., Eicheldinger, A., Muschler, P., Goerlich, O., \& Busch, U. (2014). Automated DNA extraction from pollen in honey. Food Chemistry, 149, 302-306.

Hermosín, I., Chicón, R. M., \& Dolores Cabezudo, M. (2003). Free amino acid composition and botanical origin of honey. Food Chemistry, 83, 263-268.

Kaškonienė, V., \& Venskutonis, P. R. (2010). Floral markers in honey of various botanical and geographic origins: a review. Comprehensive Reviews in Food Science and Food Safety, 9, 620-634.

Laube, I., Hird, H., Brodmann, P., Ullmann, S., Schöne-Michling, M., Chisholm, J., et al. (2010). Development of primer and probe sets for the detection of plant species in honey. Food Chemistry, 118, 979-986.

Mafra, I., Silva, S. A., Moreira, E. J. M. O., da Silva, C. S. F., \& Oliveira, M. B. P. P. (2008), Comparative study of DNA extraction methods for soybean derived food products. Food Control, 19, 1183-1190.

Ruoff, K., Luginbühl, W., Künzli, R., Bogdanov, S., Bosset, J. O., von der Ohe, K., et al. (2006). Authentication of the botanical and geographical origin of honey by Front-Face Fluorescence Spectroscopy. Journal of Agricultural and Food Chemistry, 54, 6858-6866.
Suárez-Luque, S., Mato, I., Huidobro, J. F., Simal-Lozano, J., \& Sancho, M. T. (2002) Rapid determination of minority organic acids in honey by high-performance liquid chromatography. Journal of Chromatography A, 955, 207-214.

Valentini, A., Miquel, C., \& Taberlet, P. (2010). DNA barcoding for honey biodiversity. Diversity, 2, 610-617.

Viuda-Martos, M., Ruiz-Navajas, Y., Fernández-López, J., \& Pérez-Álvarez, J. A. (2008). Functional properties of honey, propolis, and royal jelly. Journal of Food Science, 73, R117-R124.

Waiblinger, H.-U., Ohmenhaeuser, M., Meissner, S., Schillinger, M., Pietsch, K. Goerlich, O., et al. (2012). In-house and interlaboratory validation of a method for the extraction of DNA from pollen in honey. Journal of Consumer Protection and Food Safety, 7, 243-254.

Wang, X.-H., Andrae, L., \& Engeseth, N. J. (2002). Antimutagenic effect of various honeys and sugars against Trp-p-1. Journal of Agricultural and Food Chemistry 50, 6923-6928. 